\title{
PENERAPAN MODEL PEMBELAJARAN WORD SQUARE UNTUK MENINGKATKAN HASIL BELAJAR SISWA SD NEGERI 104209 SAENTIS
}

\author{
Sorta Simanjuntak, Wesly Silalahi, Winda Syafitri \\ Surel: sorta_simanjuntak@gmail.com
}

\begin{abstract}
This study aims to improve student learning outcomes by applying the Word Square learning model. This type of research is Classroom Action Research (CAR). This research was conducted at SD Negeri 104209 Saentis. The subjects are students of class IV B with a total of 29 students, while the object of this research is the improvement of student learning outcomes. Data collection techniques used are tests and observations. The results of the pretest data analysis showed that from 29 students who completed as many as 8 people (27.50\%) by exceeding the KKM $=70$ and 21 students $(72.41 \%)$ had not completed, with a class average of 53.10._Furthermore, the results of data analysis in the first cycle showed that of the 29 students who completed as many as 18 people (62.07\%) and 11 people (37.93\%) who had not completed, with an average grade of 70.86. In the second cycle, there was an increase in student learning completeness, namely from 29 students, 25 (86.21\%) were completed and 4 (13.79\%) were not completed, with the average grade of the class increasing to 80.69. The results of observations of teacher activities in the first cycle of the first meeting were $81.67 \%$ and at the second meeting of the second cycle it increased again to 93.33\%. Based on the findings from the research, it can be concluded that the application of the Word Square model can improve student learning outcomes on the theme 8 My Living Area in class IV SD Negeri 104209 Saentis 2018/2019 academic year.
\end{abstract}

Keywords: Word Square, Student Learning Outcomes, Classroom Action Research

\begin{abstract}
ABSTRAK
Penelitian ini bertujuan untuk menigkatkan hasil belajar siswa dengan menerapkan model pembelajaran Word Square. Jenis penelitian ini adalah Penelitian Tindakan Kelas (PTK). Penelitian ini dilaksanakan di SD Negeri 104209 Saentis. Subjeknya adalah siswa kelas IV B dengan jumlah 29 orang siswa, sedangkan objek penelitian ini adalah peningkatan hasil belajar siwa. Teknik pengumpulan data yang digunakan yaitu tes dan observasi. Hasil analisis data pretest menunjukkan dari 29 orang siswa yang tuntas sebanyak 8 orang $(27,50 \%)$ dengan melampaui $\mathrm{KKM}=70$ dan 21 orang siswa $(72,41 \%)$ belum tuntas, dengan nilai rata-rata kelas sebesar 53,10 . Selanjutnya hasil analisis data pada siklus I menunjukkan dari 29 orang siswa yang tuntas sebanyak 18 orang $(62,07 \%)$ dan 11 orang $(37,93 \%)$ lagi belum tuntas, dengan nilai rata-rata kelas sebesar 70,86. Pada siklus II, tampak peningkatan ketuntasan belajar siswa yaitu dari 29 orang siswa 25 orang $(86,21 \%)$ yang tuntas dan 4 orang $(13,79 \%)$ yang belum tuntas, dengan nilai rata-rata kelas meningkat menjadi 80,69. Hasil observasi kegiatan guru siklus I pertemuan pertama sebesar $81,67 \%$ dan pada pertemuan kedua siklus II meningkat kembali menjadi 93,33\%.Berdasarkan temuan dari hasil penelitian dapat disimpulkan bahwa penerapan model Word Squaredapat meningkatkan hasil belajar siswa pada tema 8 Daerah Tempat Tinggalku di kelas IV SD Negeri 104209 Saentis T.A 2018/2019.
\end{abstract}

Kata Kunci : Word Square, Hasil Belajar Siswa, Penelitian Tindakan Kelas 
Sorta Simanjuntak, Wesly Silalahi : Penerapan model ...

\section{PENDAHULUAN}

Sebuah kurikulum yang dikembangkan untuk meningkatkan kemampuan soft skills dan hard Skill yang berupa sikap, keterampilan, dan pengetahuan. Ada pada pembelajaran Kurikulum 2013 menggunakan pembelajaran tematik. meskipun demikian, masih ditemukan situasi yang kurang menggembirakan seperti rendahnya hasil belajar siswa Selanjutnya berdasarkan hasil pengamatan peneliti, ditemukan pelaksanaan pembelajaran belum sepenuhnya terlaksana dengan baik. Pembelajaran di kelas masih bersifat konvensional yang mendominasi guru dan tidak memberikan akses bagi siswa untuk berkembang secara mandiri melalui penemuan dan proses berpikirnya.

Hal lain yang dapat dilihat adalah bahwa proses pembelajaran yang dikondisikan guru tidak vervariasi. Situasi pembelajaran relative sama untuk semua tema yang ada. yang mengakibatkan minat dan motivasi belajar siswa terpendam. Pembelajaran yng mereka lakukan hanya semacam serimonial semata. Oleh karena itu, untuk memperbaiki dan meningkatkan kualitas pembelajaran dibutuhkan perbaikan pembelajaran yang membosankan menjadi menyenangkan dengan mengunakan model pembelajaran yang menarik, inovatif, serta mampu merangsang siswa untuk lebih aktif mencari dan mengolah pengetahuannya serta mempunyai rasa tanggung jawab untuk meningkatkan kemampuan memahami atau hasil belajar siswa. Sejalan dengan yang dikatakan oleh Kurniasih \& Sani (2016: 97-98), bahwa model pembelajaran Word Square mendorong pemahaman siswa terhadap materi pelajaran, melatih untuk bersikap teliti serta merangsang siswa berpikir kreatif.

\section{METODE PENELITIAN}

Penelitian ini merupakan jenis penelitian tindakan kelas (classroom action research). Suyanto (dalam Dewi, 2015:10) mengatakan bahwa "penelitian tindakan kelas adalah suatu bentuk penelitian yang bersifat reflektif dengan melakukan tindakantindakan tertentu agar dapat memperbaiki dan meningkatkan praktek-praktek pembelajaran di kelas secara lebih profesional". Penelitian ini dilakukan di kelas IV SD Negeri 104209 Saentis, Kecamatan Percut Sei Tuan, Kabupaten Deli Serdang. Waktu penelitian direncanakan selama 2 bulan pada semester II (dua) Tahun Ajaran 2018 /2019 yang dimulai dari bulan Maret sampai April 2019.

Subjek dalam penelitian tindakan kelas ini adalah 29 orang siswa kelas IV SD Negeri 104209 saentis, Kecamatan Percut Sei Tuan, Kabupaten Deli Serdang. Objek penelitiannya adalah peningkatan hasil belajar siswa pada tema 8 Tempat Tinggalku dengan meggunakan model pembelajaran Word Square. Teknik pengumpulan dalam penelitian dilakukan sesuai tujuan penelitian yakni meneliti hasil 
belajar dan dengan pelaksanaan pembelajaran.

Teknik analisis data dilakukan secara kuantitatif, Untuk mengetahui hasil belajar siswa secara individu digunakan rumus yang dikutip dari Purwanto (2011 : 207), yakni :

Nilai $=\frac{\text { skor yang diperoleh }}{\text { skor maksimum }} \times 100$
Dengan skala penilaian sebagai berikut :
90-100 = sangat baik
80-89 = baik
65-79 = cukup
$0-64=$ rendah
Hasil perhitungan skor kemudian dikonfirmasikan dengan criteria ketuntasan belajar seperti tabel ketuntasan dalam tabel 1 . sebagai berikut:

Tabel 1. Kriteria Ketuntasan Belajar

\begin{tabular}{c|c}
\hline Kriteria Ketuntasan & Kualifikasi \\
\hline$\geq 70$ & Tuntas \\
\hline$<70$ & Tidak Tuntas \\
\hline
\end{tabular}

HASIL PENELITIAN DAN PEMBAHASAN

\begin{tabular}{lcr}
\multicolumn{2}{c}{ Penerapan } & model \\
pembelajaran & Word & Square \\
menunjukkan & peningkatan & hasil
\end{tabular} belajar siswa dan persentasi keberhasilan belajar siswa secara klasikal mencapai $\geq 85 \%$ Peningkatan hasil belajar siswa mulai dari pretest, postest siklus I dan postest siklus II secara ringkas Sebelum dilakukan tindakan dari hasil pretest diperoleh nilai rata-rata kemampuan awal siswa sebesar
53,10. Setelah siklus I, berdasarkan hasil postest I rata-rata hasil belajar siswa pada tema 8 subtema 1 pembelajaran 3 dan pembelajaran 4 mengalami peningkatan dengan ratarata 70,86. Selanjutnya setelah dilakukan perbaikan pembelajaran pada siklus II tema 8 subtema 3 pembelajaran 3 dan pembelajaran 4 , berdasarkan hasil postest II diperoleh nilai rata- rata 80,69. Peningkatan rata-rata hasil belajar siswa dapat divisualisasikan pada diagram 1 . berikut: 


\section{Rata-rata Hasil Belajar Siswa}

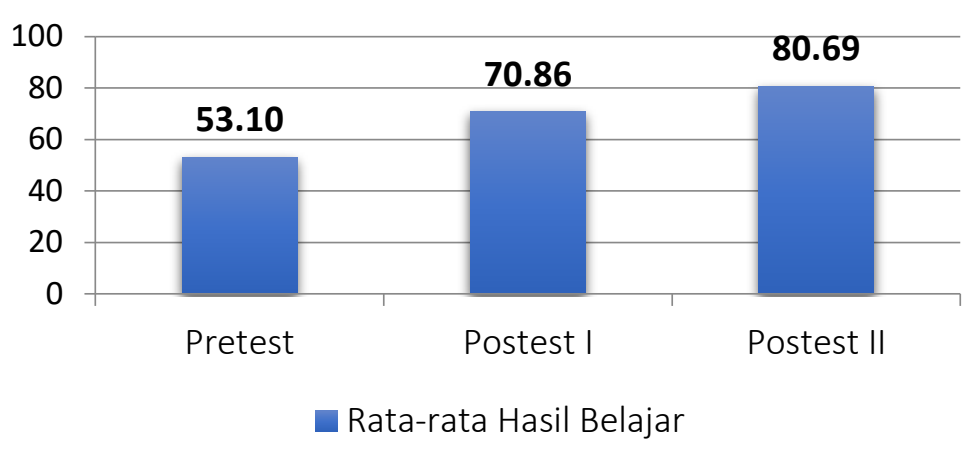

\section{Diagram 1. Perbandingan Peningkatan Rata-rata Hasil Belajar Siswa pada Pretest, Postest I dan Postest II}

Diagram 1. Perbandingan postest I diperoleh persentase Peningkatan Rata-rata Hasil Belajar keberhasilan klasikal meningkat Siswa pada Pretest, Postest I dan Postest II juga menunjukkan adanya peningkatan persentase keberhasilan belajar secara klasikal mulai dari pretest, postest I hingga postest II. Dari hasil pretest tampak persentase keberhasilan siswa secara klasikal menjadi $62,07 \%$. Selanjutnya dari hasil postest II persentase keberhasilan klasikal juga meningkat menjadi $86,21 \%$. Peningkatan keberhasilan belajar secara klasikal dapat divisualisasikan pada diagram 2. berikut: hanya $27,59 \%$, sedangkan dari hasil

\section{Peningkatan Persentase Ketuntasan Hasil Belajar Siswa}

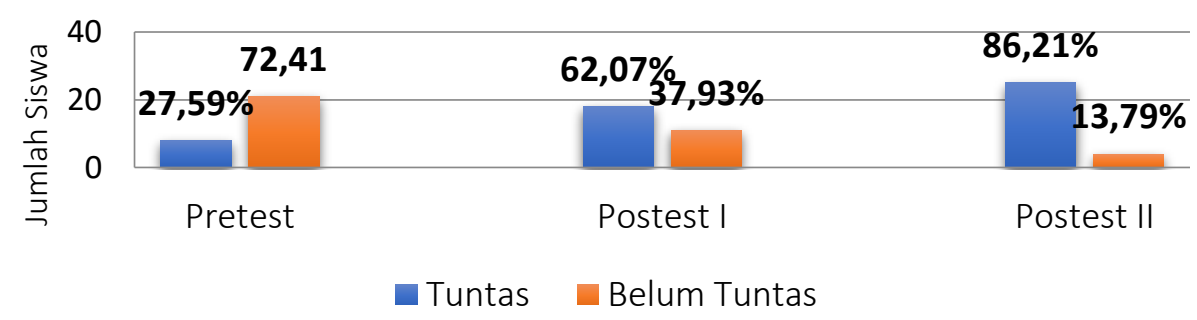

Diagram 2. Perbandingan Persentase Tingkat Ketuntasan Hasil Belajar Siswa Secara Klasikal 


\section{Pembahasan}

Berdasarkan hasil-hasil temuan peneliti, menunjukkan bahwa rata-rata kemampuan awal siswa adalah: 53,10 dengan keberhasilan siswa secara klasikal 27,59\%.

Dari hasil postest siklus II diperoleh rata-rata hasil belajar siswa sebesar 81,55 dengan persentase ketuntasan secara klasikla sebesar $89,66 \%$.

Hasil penelitian menunjukkan bahwa melalui kegiatan pembelajaran dengan menggunakan model pembelajaran word square dapat meningkatkan hasil belajar siswa di kelas V SD Negeri Bintoro 13 Demak pada pembelajaran tema 3 Makanan Sehat subtema 2 Pentingnya Makanan Sehat. Dari analisis akhir dengan menggunakan uji $\mathrm{t}$ menunjukkan hasil $\mathrm{t}$ hitung $>\mathrm{t}$ tabel yaitu 8,1575>2,064.

Sehingga dapat disimpulkan bahwa model pembelajaran Word Square dapat meningkatkan hasil belajar siswa pada tema 8 Daerah Tempat Tinggalku kelas IV SD Negeri 104209 Saentis T.A 2018/2019.

\section{SIMPULAN}

Berdasarkan hasil penelitian, analisis dan refleksi dari tiap-tiap siklus dapat disimpulkan:

- Dari penelitian yang dilakukan, sebelum diberi tindakan dari hasil pretest 29 orang siswa diperoleh rata-rata kemampuan awal siswa sebesar 53,10 dengan persentase keberhasilan klasikal belajar siswa yaitu $27,59 \%$ atau dari 29 orang siswa hanya 8 orang siswa yang memperolah nilai tuntas.

- Aktivitas siswa dalam aspek afektif dan psikomotor selama proses pembelajaran dengan tindakan penerapan model pembelajaran Word Square dari siklus I sampai ke siklus II terus mengalami peningkatan.

- Aktivitas peneliti selama proses pembelajaran dengan menerapkan model pembelajaran Word Square pada siklus I sudah tergolong baik dan pada siklus II menjadi sangat baik atau aspek yang diamati berdasarkan format lembar observasi yang ada seluruhnya telah dilaksanakan.

\section{DAFTAR RUJUKAN}

Arikunto, Suharsimi. 2012. Dasardasar Evaluasi Pendidikan. Jakarta: Bumi Aksara.

Eveline \& Hartini. 2014. Teori Belajar dan Pembelajaran. Bogor: Ghalia Indonesia.

Hamalik, Oemar. 2016. Proses Belajar Mengajar. Jakarta: Bumi Aksara.

Ihram, M \& Novan A. Wiyani. 2013. Psikologi Pendidikan Teori dan Aplikasi dalam Proses Pembelajaran. Yogjakarta: ArRuzz Media.

Istarani. 2017. 58 Model Pembelajaran Inovatif. Medan: Media Persada.

Istirani \& Intan. 2017. Ensiklopedia Pendidikan. Medan: Media Persada.

Kadir, H.A \& Hanun Asrohah. 2014. Pembelajaran Tematik. Jakarta: Raja Grafindo Persada. 
Sorta Simanjuntak, Wesly Silalahi : Penerapan model ...

Kurniasih, Imas \& Berlin Sani. 2016. Ragam Pengembangan Model Pembelajaran

Untuk

Peningkatan Profesionalitas

Guru. Yogyakarta : Kata Pena.

Mardianto. 2012. Pembelajaran

Tematik. Medan: Perdana Publishing.

Nurmayani. 2018. Penggunaan Model Pembelajaran Word Square untuk Meningkatakan Hasil Belajar Siswa Pada Pelajaran Pendidikan Kewarganegaraan Di Kelas V SD Negeri 054938 Kab.
Langkat. School Education Journal. Vol 8 (1), hal: 35-47. (https://jurnal.unimed.ac.id/201 2/index.php/school/article/dow nload/9781/9228). (online). Diakses pada tanggal 10 Desember 2018.

Priansa, Donni J. 2017. Pengembangan Strategi dan Model Pembelajaran. Bandung: Pustaka Setia.

Purwanto. 2011. Evaluasi Hasil Belajar. Yogyakarta: Pustaka Belajar. 